\title{
Development and Preliminary Psychometric Evaluation of the Dimensional Clinical Personality Inventory - Schizoid Personality Disorder Scale
}

\author{
Lucas de Francisco Carvalho ${ }^{1}$ (D), Ana Paula Salvador (D), André Pereira Gonçalves (D) \\ Universidade São Francisco, Campus Swift, Campinas-SP, Brasil
}

\section{ABSTRACT}

A new dimensional-based framework was proposed, the Hierarchical Taxonomy of Psychopathology (HiTOP). This study aimed to develop a specific version of the Dimensional Clinical Personality Inventory 2 (IDCP-2), focused on the assessment of the schizoid personality disorder (SZPD) according to the HiTOP. In stage 1, we developed a new factor to cover all SZPD traits, as presented in the HiTOP. Six factors (one new and five from the IDCP-2) composed the IDCP-SZPD. In stage 2, 434 adults from the community, aged from 18 to 67 years $(M=31.6, S D=9.7)$, completed factors from three self-report measures: the IDCP-SZPD, PID-5, and FFaVA. The IDCP-SZPD factors and total score presented high reliability. Correlations and a bootstrap two-sample t-test comparison corroborated the expectations. Although we found evidence supporting the use of the IDCP-SZPD for the measurement of SZPD traits, further research is needed to verify the replicability of the present findings in samples composed of SZPD patients.

Keywords: personality disorders; diagnosis; personality assessment; cluster A; psychometrics.

RESUMO - Desenvolvimento e Avaliação Psicométrica Preliminar do Inventário Dimensional Clínico da Personalidade - Escala Transtorno da Personalidade Esquizoide

Um novo framework dimensional foi proposto, o Hierarchical Taxonomy of Psychopathology (HiTOP). O objetivo deste estudo foi desenvolver uma versão específica do Inventário Dimensional Clínico da Personalidade 2 (IDCP-2), com foco na avaliação do transtorno da personalidade esquizoide (TPE) de acordo com o HiTOP. No estágio 1, foi desenvolvido um novo fator, buscando cobrir todos os traços do TPE apresentados no HiTOP. Compuseram o IDCP-SZPD seis fatores (um novo e cinco do IDCP-2). No estágio 2, 434 adultos da população geral, com idade entre 18 e 67 anos $(M=31.6 ; D P=9,7)$, completaram fatores de três medidas de autorrelato: IDCP-SZPD, PID-5 e FFaVA. Os fatores do IDCP-SZPD e o escore total apresentaram alta precisão. Correlações e comparações via bootstrap two-sample $t$ teste corroboraram as expectativas. Embora evidências favoráveis tenham sido observadas para o uso do IDCP-SZPD, na avaliação de traços do TPE, estudos futuros devem verificar a replicabilidade dos achados em amostras de pacientes com TPE.

Palavras-chave: transtornos da personalidade; diagnóstico; avaliação da personalidade; cluster A; psicometria.

RESUMEN - Desarrollo y Evaluación Psicométrica Preliminar del Inventario Dimensional Clínico de Personalidad Escala del Trastorno Esquizoide de la Personalidad

Un nuevo framework dimensional fue propuesto, el Hierarchical Taxonomy of Psychopathology (HiTOP). El objetivo fue el de desarrollar una versión específica del Inventario Dimensional Clínico de Personalidad 2 (IDCP-2), centrado en la evaluación del trastorno esquizoide de la personalidad (TPE) según el HiTOP. En la etapa 1 se desarrolló un nuevo factor para cubrir todos los rasgos del TPE presentados en el HiTOP. Seis factores (uno nuevo y cinco del IDCP-2) compusieron el IDCP-SZPD. En la etapa 2, 434 adultos de la comunidad, con edades comprendidas entre 18 y 67 años $(\underline{X}=31,6, D S=9,7)$, completaron los factores de tres medidas de auto-informe: IDCP-SZPD, PID-5 y FFaVA. Los factores del IDCP-SZPD y el puntaje total mostraron una alta confiabilidad. Las correlaciones y la comparación del bootstrap two-sample $t$ test corroboraron las expectativas. Aunque se observaron evidencias favorables para el uso de la IDCP-SZPD para la medición de rasgos de TPE, los estudios posteriores deberían verificar la replicabilidad de los presentes hallazgos en muestras compuestas por pacientes con TPE.

Palabras clave: desorden de personalidad; diagnóstico; evaluación de la personalidad; cluster A; psicometría.

Schizoid personality disorder (SZPD) onset is usually in early adulthood, with a prevalence of approximately 5\% in the general population (APA, 2013; Sadock,
Sadock \& Ruiz, 2017). In clinical samples, it is one of the less frequent PD, with prevalence equal to $2.2 \%$ (Triebwasser, Chemerinski, Roussos, \& Siever, 2012). 
SZPD refers to a pattern of detachment in interpersonal relationships and restrictive emotional expressions (APA, 2013; Triebwasser et al., 2012). Social anhedonia, preference for solitary activities, indifference to praise or criticism, lack of interest in intimate relationships, decreased sexual libido, and emotional coldness are typical traits of SZPD (Dammann, 2017; Esterberg, Goulding, \& Walker, 2010; Hummelen, Pedersen, Wilberg, \& Karterud, 2015; Millon, 2011; Mulay \& Cain, 2017). Generally, an individual diagnosed with SZPD tends to be withdrawn, isolated, and bored (Esterberg et al., 2010; Krueger, Derringer, Markon, Watson, \& Skodol, 2012; Millon, Millon, Meagher, Grossman, \& Ramnath, 2004).

The Diagnostic and Statistical Manual of Mental Disorders (DSM), currently in its fifth edition (DSM5; APA, 2013), is based on the categorical approach and represents the official guidelines on how to diagnose PD, including the SZPD. Criticisms and limitations of the categorical approach have been discussed in the literature in the past few decades, suggesting its inadequacy in assessing and diagnosing PD (Krueger et al., 2011), and the advantage in using an alternative approach, such as the dimensional model (Hummelen et al., 2015).

As the dimensional models help to better account for the categorical limitations (Crawford, Koldobsky, Mulder, \& Tyrer, 2011; Huprich et al., 2018; Matos, Matos, Mello, Matos, \& Mello, 2005; Kotov et al., 2017), a new dimensional-based framework has been proposed. The Hierarchical Taxonomy of Psychopathology (HiTOP; Conway et al., 2019; Kotov et al., 2017; Kotov, Krueger, \& Watson, 2018), a model based on literature reviews from empirical findings, diagnostic co-occurrence studies, and found a consistent pattern of covariance and factor analytic organization in several disorders. The HiTOP is composed of hierarchical levels, i.e., super spectra, spectra, subfactors, syndromes/disorders, components, and symptoms. SZPD is represented in the HiTOP model by the Detachment spectrum, including the following traits: anhedonia, depressivity, intimacy avoidance, suspiciousness, withdrawal, interpersonal passivity, disaffiliativeness, and low attention-seeking.

In addition to updating according to a current model, assessment tools developed or improved according to the HiTOP can provide information on the presence of pathological traits that seem to cause impairment in individuals' lives (Kotov et al., 2017). According to the model, these evaluative tools can present information based on the pathological traits, which are relevant to the different hierarchical levels of the taxonomy of PD (Conway et al., 2019), without repeating the limitation of the categorical models (Haslam et al., 2012).

Kotov et al. (2017) summarized assessment tools related to traits, syndromes, subfactors, and spectra of the HiTOP. Although not specifically developed to measure SZPD, the Minnesota Multiphasic Personality Inventory 2 (MMPI-2), the Personality Inventory for DSM-5 (PID-5), and the Five-Factor Measure of Avoidant Personality (FFvA) are examples of scales that can be used to the assessment of traits composing this PD. Most of these scales are not available for LatinAmerican countries, such as in Brazil, where this study took place. This is a substantial gap identified almost a decade ago (Carvalho, Bartholomeu, \& Silva, 2010).

One of the few self-report scales for pathological traits assessment, available in the Brazilian context, is the Dimensional Clinical Personality Inventory 2 (IDCP-2; Carvalho \& Primi, in press). IDCP-2 is composed of 206 items, organized into 47 factors. These factors can be grouped into 12 dimensions. Previous studies were conducted to review and update IDCP-2 factors and dimensions according to the DSM-5 and other sources (e.g., Carvalho \& Silva, 2016; Carvalho, Sette, \& Ferrari, 2016). One previous study suggested the accordance between the IDCP-2 factorial structure and the spectra structure of the HiTOP (Pianowski, Carvalho, \& Miguel, 2019). Moreover, specifically on SZPD, evidence suggests good discriminant and predictive capacities of IDCP-2 dimensions, mainly, Isolation, Criticism Avoidance, Mood Instability, and Eccentricity (Abela, 2013; Carvalho \& Primi, 2015; 2016; Carvalho \& Arruda, 2016).

Considering the HiTOP proposal as the state of art in mental health, including the typical traits related to $\mathrm{PD}$, and specifically SZPD, we aimed to develop a specific version of the IDCP-2, the IDCP Schizoid Personality Disorder Scale; IDCP-SZPD), focused on the assessment of traits related to SZPD in accordance to the HiTOP. Additionally, we presented initial evidence of its psychometric properties, investigating the suitableness of the scale in measuring SZPD traits. Therefore, we developed in this study a specific version of IDCP2 for SZPD, according to HiTOP. This new version is composed of factors from IDCP-2 as well as by new items (and factors) presently developed.

\section{Methods}

The method was divided into two stages, according to the scope of the research. In the first stage, we detailed procedures related to the review of IDCP-2, according to the HiTOP, focusing on the typical features of SZPD. In the second stage, we verified the psychometric properties of the IDCP-2 version developed, the IDCP-SZPD.

\section{Stage 1 - Development of the IDCP Schizoid Personality Disorder Scale (IDCP-SZPD) according to HiTOP}

We first verified which spectra of HiTOP encompassed SZPD traits. Traits from these spectra were selected when considered relevant. We deliberately attempt to maintain as many traits as possible, aiming at the representativeness of typical SZPD traits. Based on Table 1 from Kotov et al. (2017), we identified definitions for 
each selected trait. Definitions were extracted from the Personality Inventory for DSM-5 (PID-5; Krueger et al., 2012) and the Minnesota Multiphasic Personality Inventory (MMPI-2; Butcher et al., 1989). These definitions were used in the matching between selected traits and the 47 factors from the IDCP-2. As gaps were identified, we independently developed items for traits not covered by any IDCP-2 factors. We then selected the most suitable items based on content and semantic characteristics. Specifically, clarity, consistency, and redundancy of items were verified. The first version of the IDCP-SZPD was produced by these procedures and subjected to empirical verification.

\section{Stage 2 - Psychometric Study of the IDCP Schizoid Personality Disorder Scale (IDCP-SZPD)}

\section{Participants}

Data collection was by convenience sampling. The Sample was composed of 434 people from the community. Participants aged from 18 to 67 years $(M=31.6$, $S D=9.7)$, mainly female $(66.7 \%)$, Caucasian $(76 \%)$, and mostly reporting more than 10 years of education (49.8\%). 47.6\% reported having participated in psychotherapy, and $19.6 \%$ reported having received psychiatric treatment. Some participants reported past suicidal ideation $(36.2 \%)$, suicide attempts $(6.4 \%)$, and currently suicidal ideation (5\%). Based on this information, although being a community sample, the occurrence of SZPD traits was likely.

The expectation for SZPD occurrence in community samples is around 5\% (APA, 2013). In an epidemiologic study in the São Paulo Metropolitan Area, Brazil, $4.3 \%$ cases of PD from Cluster A were observed (Santana et al., 2018). According to this, for the present study, people with elevation in typical traits of the SZPD were expected, although a small number of people with SZPD diagnosis should be found.

\section{Measures}

The IDCP Schizoid Personality Disorder Scale, IDCP-SZPD, is a scale originated from The Dimensional Clinical Personality Inventory 2 (IDCP-2; Carvalho \& Primi, in press) based on the traits of the SZPD according to the HiTOP (Kotov et al., 2017; Conway et al., 2019). The IDCP-2 consists of a self-report measure developed to assess pathological personality traits, comprising 206 items on a Likert 4-point scale, from "has nothing to do with me" to "everything to do with me". The IDCP-2 covers 47 factors on 12 dimensions (i.e., Dependency, Aggressiveness, Mood Instability, Eccentricity, Attention Seeking, Distrust, Grandiosity, Isolation, Criticism Avoidance, Self-sacrifice, Conscientiousness, and Inconsequence). We administered five factors from three dimensions: Eccentricity dimension (interpersonal detachment; Carvalho, Pianowski, Silveira, Bacciotti, \&
Vieira, 2016); Isolation dimension (individualism, social isolation factor, and intimacy avoidance; Carvalho \& Arruda, 2016), Criticism avoidance dimension (intimate relationships avoidance factors; (Carvalho \& Sette, 2017). Besides, the IDCP-SZPD version is also composed of the new interpersonal passivity factor, best described further in this paper.

The Personality Inventory Disorder for DSM-5 (PID-5; Krueger et al., 2012) is a self-report inventory designed to assess 25 facets representing pathological characteristics of personality according to the Alternative Model for Personality Disorders (AMPD) of the DSM-5 (APA, 2013). It contains 220 items on a Likert 4-point scale, from "false or often false" to "true or often true". The 25 facets are grouped into five dimensions (i.e., Negative Affect, Detachment, Antagonism, Disinhibition, and Psychoticism). For this study, we selected the following facets: anhedonia $(\alpha=.88)$, anxiety $(\alpha=.91)$, intimacy avoidance $(\alpha=.84)$, restricted affectivity $(\alpha=.75)$, and withdrawal $(\alpha=.93)$. Psychometric properties of the PID-5 were previously investigated (Krueger et al., 2012; Al-Dajani, Gralnick \& Bagby, 2016).

The Five-Factor Model Personality Disorder scales (FFM-PD scales; Widiger \& Costa, 2012; Widiger, Lynam, Miller, \& Oltmanns, 2012) aim to evaluate pathological traits based on the Five-Factor model and is composed of five domains assessing 99 traits. Items must be answered on a Likert 5-point scale ranging from "strongly disagree" to "strongly agree". The FFM-PD has shown satisfactory psychometric properties (DeShong, Lengel, Sauer-Zavala, O'Meara, \& Mullins-Sweatt, 2015; Gore, Tomiatti, \& Widiger, 2011; Mullins-Sweatt et al., 2012; Tomiatti et al., 2012; Widiger et al., 2012). For this study, we included the joylessness $(\alpha=.82)$ factor from the Five-Factor Avoidant Assessment (FFAvA; Lynam, Loehr, Miller, \& Widiger, 2012).

\section{Procedure}

This study adhered to the ethical research procedures set by the Declaration of Helsinki (WMA, 2013), and was approved by a Brazilian Research Ethics Committee (CAAE: 21992113.1.0000.5514). We performed online data collection using Google Forms, inviting volunteers through social networking sites (e.g., Facebook). The protocol consisted of a term to attest to voluntary participation and demographic questions and items from the scales. The volunteers dedicated approximately 30 minutes to respond to the survey. After four weeks of data collection, we extracted the database for analyses.

\section{Data analyses}

In step 1, we selected the relevant traits for the SZPD according to HiTOP, which are presented in Table 1. From this selection, new items were developed, and new factors established, achieving the version of the 
IDCP-SZPD that was administered. In step 2, psychometric properties were verified through the exploratory structural equation modeling (E-SEM), using parallel analysis as an indicator of the number of factors. We calculated the internal consistency and intracorrelations as indicators of reliability. Correlations were performed between the IDCP-SZPD factors and the respective external measures, according to Table 1 . We also proceeded to bootstrap $(k=10.000$; bias-corrected $95 \%$ confidence intervals - CI) two-sample t-test, creating two groups from the total sample: the healthy group $(n=156)$, composed of people that related never having done psychotherapy and psychiatric treatment, and also reported no suicide attempt or suicidal thoughts, and the pathological group $(n=62)$, composed of people that reported having at least one psychiatric diagnosis and participate in psychiatric treatment. We use R software version 3.4.0 for parallel analysis calculation, MPlus software version 7 for E-SEM, and SPSS software version 21 for reliability, correlations and test $t$ with bootstrap. The $p$-value level was $p \leq .05$.

\section{Results}

IDCP-2 revision procedures according to pathological traits from Schizoid related spectra of the HiTOP model.

Table 1 presents the spectra related to SZPD from the HiTOP model, as well as the traits composing these spectra, relevant traits for SZPD selected independently by the authors of this research and the external measures respective for each IDCP-2 factors and new factors.

Table 1

Selected traits, IDCP-2 Factors, Developed Measures, and External Measures Based on SZPD Spectra from HiTOP

\begin{tabular}{|c|c|c|c|c|}
\hline Spectrum & Traits & Selected traits & $\begin{array}{c}\text { IDCP-2 factors and } \\
\text { developed measures }\end{array}$ & $\begin{array}{c}\text { Respective } \\
\text { external measures }\end{array}$ \\
\hline \multirow{11}{*}{ Detachment } & \multirow{5}{*}{$\begin{array}{c}\text { Anhedonia } \\
\text { Depressivity } \\
\text { Intimacy Avoidance } \\
\text { Suspiciousness }\end{array}$} & \multirow{3}{*}{ Anhedonia } & Anhedonia & \multirow{2}{*}{$\begin{array}{c}\text { Joylessness (FFAvA); } \\
\text { Anhedonia (PID-5) }\end{array}$} \\
\hline & & & (6 items $\rightarrow 4$ items) & \\
\hline & & & & \multirow{3}{*}{$\begin{array}{c}- \\
\text { Intimacy avoidance } \\
\text { (PID-5) }\end{array}$} \\
\hline & & \multirow{2}{*}{ Intimacy avoidance } & Intimate relationships & \\
\hline & & & avoluaile & \\
\hline & \multirow{3}{*}{$\begin{array}{l}\text { Withdrawal } \\
\text { Interpersonal } \\
\text { Passivity }\end{array}$} & \multirow{3}{*}{$\begin{array}{l}\text { Withdrawal } \\
\text { Interpersonal } \\
\text { Passivity }\end{array}$} & \multirow{2}{*}{$\begin{array}{l}\text { Intimacy avoidance; } \\
\text { Individualism }\end{array}$} & \multirow{2}{*}{ Withdrawal (PID-5) } \\
\hline & & & & \\
\hline & & & - & - \\
\hline & \multirow{3}{*}{$\begin{array}{l}\text { Disaffiliativeness } \\
\text { (low) Attention } \\
\text { Seeking }\end{array}$} & \multirow{2}{*}{$\begin{array}{c}\text { Disaffiliativeness } \\
--\end{array}$} & \multirow{2}{*}{$\begin{array}{l}\text { Social isolation; } \\
\text { Interpersonal } \\
\text { detachment }\end{array}$} & \multirow{2}{*}{$\begin{array}{l}\text { Restricted affectivity } \\
\text { (PID-5) }\end{array}$} \\
\hline & & & & \\
\hline & & & -- & -- \\
\hline
\end{tabular}

Note. new factors are bolded; in brackets are the number of items developed to the new factor and the final number of items

From the Detachment spectrum, we selected five traits as core relevant for SZPD. Therefore, seeking to cover all traits, six items for one factor were created, and we selected four items to be administered in Stage 2. Items that were selected followed criteria for clarity, consistency, content, and (non-redundancy). The new factor was labeled as Anhedonia. The five remaining factors were selected from IDCP-2.

\section{Psychometric properties verification of the IDCP-SZPD}

We investigated the psychometric properties of measures, starting from the parallel analysis for polychoric variables, determining the maximum number of factors for the IDCP-SZPD. We obtained up to one factor, with significant eigenvalues not randomly established, and proceeded to the exploratory structural equation modeling (E-SEM; Marsh, Morin, Parker, \& Kaur, 2014), testing a one-factor solution using the Geomin oblique rotation and extraction method MLR, a maximum likelihood estimation with robust standard errors that are robust to non-normality.

Indexes of the model were verified. The fit indexes obtained were $\chi^{2} / d f=3.04$ (poor); RMSEA $=.07$ (acceptable); $\mathrm{CFI}=.97$ (good); TLI $=.94$ (good); and SMR $=.04$ (good), based on Hooper, Coughlan, and Mullen (2008). Table 2 shows factors loadings, average of the correlations between the measures composing the factor; and internal consistency (Cronbach's $\alpha$ and McDonald $\Omega$ ) for measures. 
Table 2

Factor Loadings of IDCP-2 Measures and Developed Measures

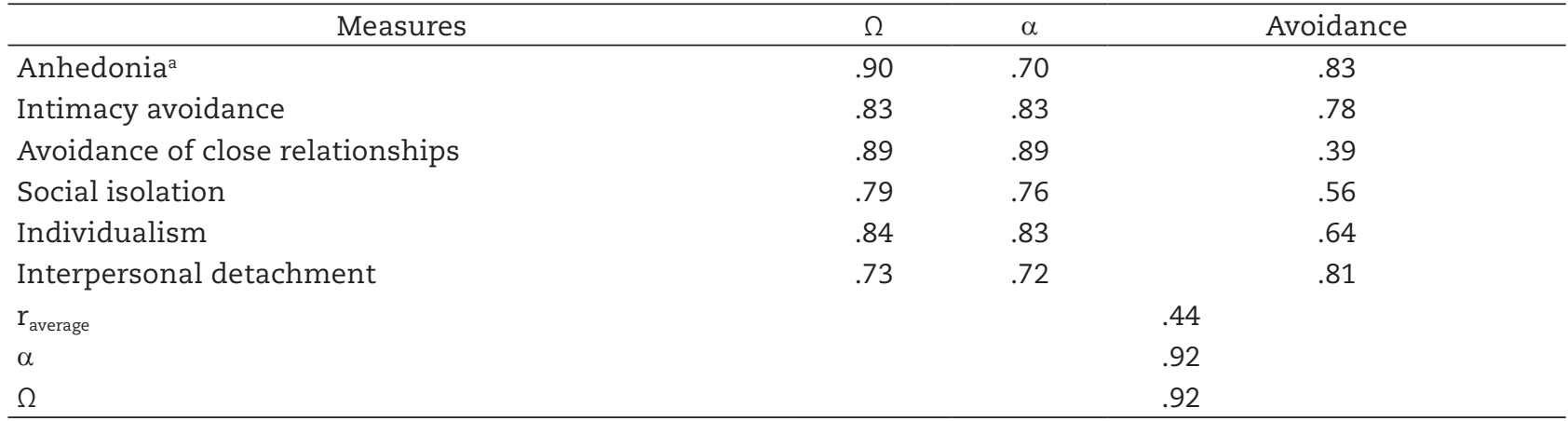

Note. a developed measure

Internal consistency based on alpha was $\geq .70$ and based on omega $\geq .73$, and the overall consistency was higher than .90 in both. The average correlations of measures composing the factor sugge consistency. Table 3 presents the correlations between IDCP-2 measures and the three of the four factors found with PID-5, FFBI, and FFHI measures administered.
We observed the expected correlations, although for Interpersonal detachment larger effect sizes were found with other measures (i.e., Anhedonia and Withdrawal). Even in this case, the correlation with the expected external measure was one of the highest. Total score correlations showed that IDCP-SZPD has a moderate to high correlation with all external measures. Table 4 presents results on healthy and pathological groups comparison.

Table 3

Correlations Between IDCP-2 Measures, New Measure, and Factors from PID-5 and FFaVa

\begin{tabular}{|c|c|c|c|c|c|}
\hline & \multirow{2}{*}{$\frac{\text { FFAvA }}{\text { Joy. }}$} & \multicolumn{4}{|c|}{ PID-5 } \\
\hline & & Anhedonia & Int. Avo. & Withdrawal & Rest. Affec. \\
\hline Anhedonia & $.62^{* *}$ & $.77^{* *}$ & $.37^{* *}$ & $.74^{* *}$ & $.59^{* *}$ \\
\hline Intimacy Avoidance & $.40^{* *}$ & $.49^{* *}$ & $.30^{* *}$ & $.71^{* *}$ & $.48^{* *}$ \\
\hline Avoidance of close relationships & $.26^{* *}$ & $.24^{* *}$ & $.77^{* *}$ & $.38^{* *}$ & $.39^{* *}$ \\
\hline Social isolation & $.28^{* *}$ & $.34^{* *}$ & $.39^{* *}$ & $.57^{* *}$ & $.53^{* *}$ \\
\hline Individualism & $.46^{* *}$ & $.52^{* *}$ & $.26^{* *}$ & $.59^{* *}$ & $.44^{* *}$ \\
\hline Interpersonal detachment & $.50^{* *}$ & $.62^{* *}$ & $.30^{* *}$ & $.73^{* *}$ & $.50^{* *}$ \\
\hline IDCP-SZPD total score & $.58^{* *}$ & $.68^{* *}$ & $.54^{* *}$ & $.84^{* *}$ & $.66^{* *}$ \\
\hline
\end{tabular}

Note. Joy.=Joylessness; Int. Avo.=Intimacy Avoidance; Rest. Affec.=Restricted Affectivity; Att. Seek.=Attention Seeking. Expected correlations between IDCP-2 factors and respective external measures, according to Table 1, are in bold. ${ }^{* *}$ Correlation is significant at the 0.01 level; * Correlation is significant at the 0.05 level

Table 4

Comparison Between Healthy $(n=156)$ and Pathological $(n=62)$ Groups in Factors from IDCP-SZPD

\begin{tabular}{|c|c|c|c|c|c|c|c|c|}
\hline \multirow{2}{*}{ Factors } & \multirow{2}{*}{ Groups } & \multirow{2}{*}{ Mean } & \multirow{2}{*}{ SD } & \multicolumn{2}{|c|}{ BCa 95\% CI } & \multirow{2}{*}{$t$} & \multirow{2}{*}{$d f$} & \multirow{2}{*}{$p(d)$} \\
\hline & & & & Lower & Upper & & & \\
\hline \multirow{2}{*}{ Anhedonia } & + & 1.4071 & .54 & 1.3266 & 1.4931 & \multirow{2}{*}{-8.258} & \multirow{2}{*}{216} & \multirow{2}{*}{$.001(1.24)$} \\
\hline & - & 2.2581 & .96 & 2.0286 & 2.4763 & & & \\
\hline \multirow{2}{*}{ Intimacy Avoidance } & + & 1.2660 & .46 & 1.2020 & 1.3362 & \multirow{2}{*}{-6.097} & \multirow{2}{*}{216} & \multirow{2}{*}{$.001(.91)$} \\
\hline & - & 1.8105 & .85 & 1.6250 & 1.9979 & & & \\
\hline \multirow{2}{*}{ Avoidance of close relationships } & + & 1.3526 & .61 & 1.2627 & 1.4456 & \multirow{2}{*}{-2.859} & \multirow{2}{*}{216} & \multirow{2}{*}{$.018(.43)$} \\
\hline & - & 1.6371 & .78 & 1.4583 & 1.8278 & & & \\
\hline
\end{tabular}


Table 4 (continuation)

Comparison Between Healthy $(n=156)$ and Pathological $(n=62)$ Groups in Factors from IDCP-SZPD

\begin{tabular}{|c|c|c|c|c|c|c|c|c|}
\hline \multirow{2}{*}{ Factors } & \multirow{2}{*}{ Groups } & \multirow{2}{*}{ Mean } & \multirow{2}{*}{ SD } & \multicolumn{2}{|c|}{ BCa $95 \%$ CI } & \multirow{2}{*}{$t$} & \multirow{2}{*}{$d f$} & \multirow{2}{*}{$p(d)$} \\
\hline & & & & Lower & Upper & & & \\
\hline \multirow{2}{*}{ Social isolation } & + & 1.7067 & .57 & 1.6167 & 1.7975 & \multirow{2}{*}{-3.090} & \multirow{2}{*}{216} & \multirow{2}{*}{$.010(.47)$} \\
\hline & - & 1.9960 & .73 & 1.8059 & 2.1758 & & & \\
\hline \multirow{2}{*}{ Individualism } & + & 1.7553 & .66 & 1.6501 & 1.8571 & \multirow{2}{*}{-7.052} & \multirow{2}{*}{216} & \multirow{2}{*}{$.001(1.06)$} \\
\hline & - & 2.5054 & .81 & 2.2836 & 2.7293 & & & \\
\hline \multirow{2}{*}{ Interpersonal detachment } & + & 1.5705 & .57 & 1.4798 & 1.6645 & \multirow{2}{*}{-9.086} & \multirow{2}{*}{216} & \multirow{2}{*}{$.001(1.37)$} \\
\hline & - & 2.4785 & .85 & 2.2666 & 2.6871 & & & \\
\hline \multirow{2}{*}{ IDCP-SZPD total score } & + & 1.51 & .39 & 1.4473 & 1.5719 & \multirow{2}{*}{-8.53} & \multirow{2}{*}{216} & \multirow{2}{*}{$<.001(1.26)$} \\
\hline & - & 2.11 & .64 & 1.9503 & 2.2641 & & & \\
\hline
\end{tabular}

Note. (+) healthy group; (-) pathological group

Higher means for the pathological group were observed for all factors. Those comparisons were statistically significant, and effect sizes were typically large or very large (Sawilowsky, 2009).

\section{Discussion}

Traditional diagnostic models, such as the DSM-5 section II (APA, 2013), contributed to the improvement in the PD diagnostic, presenting symptoms categories composing each disorder (Oldham, 2018). However, problems with the categorical system of PD diagnosis have been widely recognized (Samuel \& Griffin, 2015; Haslam et al., 2012; Kotov et al., 2017; Teesson, Slade, \& Mills, 2009). Aiming to mitigate the problems of the categorical system, the HiTOP proposition was empirically-based (Kotov et al., 2017). This study aimed to develop a specific version of the IDCP-2 based on the HiTOP for the assessment of schizoid traits, the IDCPSZPD. The findings showed favorable psychometric evidence for the IDCP-SZPD, suggesting that the scale measures the traits considered as relevant according to HiTOP and specific literature on SZPD (APA, 2013; Dammann, 2017; Esterberg et al., 2010; Hummelen et al., 2015; Krueger et al., 2012; Millon, 2011; Mulay \& Cain, 2017).

As IDCP-2 factors were not covering all relevant traits for SZPD, new items were developed, aiming for the expansion in coverage of SZPD, and the establishment of the IDCP-SZPD (Table 1). From the eight traits composing the Detachment spectra (Kotov et al., 2017), five were select as substantial for SZPD assessment, according to literature (Dammann, 2017; Esterberg et al., 2010; Hummelen et al., 2015; Millon, 2011; Mulay \& Cain, 2017). Four traits were covered by IDCP-2 factors (see Carvalho \& Arruda, 2016; Carvalho et al., 2016), and although any of these factors covered the Anhedonia trait, they seemed as relevant for SZPD (Kotov et al., 2017). We developed items for the new Anhedonia factor, regarding the lack of energy and pleasure with life (Krueger et al., 2012). This factor composition represents the IDCP-SZPD, and presumably encompasses the core traits of the SZPD.

Findings on factorial structure were consistent with HiTOP (Conway et al., 2019; Kotov et al., 2017), suggesting that the six SZPD core symptoms are related and compose a single high order factor. This high order factor was called Avoidance, which includes the core SZPD symptoms according to HiTOP, as general and intimacy interpersonal detachment and avoidance (Kotov et al., 2017). Internal consistency coefficients also corroborated the unidimensional solution (Hattie, 1985; Tavakol \& Dennick, 2011), and can be interpreted as good for clinical use of the scale (AERA, APA, \& NCME, 2013; Nunnally, 1978).

In general, correlations between the IDCP-ASZPD factors and the external measures corroborated expectations (see Table 1). However, three factors correlated with the PID-5 Withdrawal factor from more than we expected with external measures. This trait can be conceptualized as the preference for being alone, discretion and avoidance in social situations, and lack of initiation of social contact (APA, 2013). As the core SZPD symptoms are detachment from social situations and restricted emotional expression in different contexts (APA, 2013; Triebwasser et al., 2012), it is coherent that the Withdrawal factor presented high correlations with other SZPD relevant traits, behaving as a global indicator of this PD. The correlation between total score and Withdrawal corroborate this interpretation, although correlations with total score were at least moderate (Cohen, 1992). Moreover, two correlations as high as expected were observed, Individualism with Anhedonia and Interpersonal Detachment with Joylessness. While not expected, it is reasonable for individuals who prefer to stay alone most of the time to tend to express anhedonia, and for individuals who are uninterested in establishing interpersonal relationships $\mathrm{t}$ to tend to experience less joy (APA, 2013; Young et al., 2016). 
Groups comparison through bootstrap t-test indicated a good capacity of the IDCP-SZPD factors, varying from marginally moderate to very large differences (Sawilowsky, 2009). The pathological group presented higher means for all factors in comparison to the healthy group. Anhedonia, Interpersonal Detachment, and Individualism factors showed the largest differences, which is coherent considering that they represent some of the core traits of the SZPD (APA, 2013; Dammann, 2017; Esterberg et al., 2010; Hummelen et al., 2015; Kotov et al., 2017; Millon, 2011; Mulay \& Cain, 2017).

In this study, we presented primary evidences on the IDCP-SZPD psychometric properties. Although initial, our findings support the clinical applicability of the test. Limitations of the study must be weighted. The community sample was not assessed in order to assure that people considered as "healthy" indeed did not have SZPD or other PD diagnoses. Studies with diagnostic accuracy designs must be conducted seeking for the cutoff establishment of the IDCP-SZPD.

\section{Acknowledgements}

Not applicable.

\section{Funding}

The research did not receive any funding source and it is funded by the authors' own funds.

\section{Authors' contributions}

All authors contributed substantially to the elaboration of the research design, analysis, and interpretation of the data, as well as to the textual review and approval of the final version of this study. All authors assume public responsibility for the content of the manuscript.

\section{Availability of data and materials}

All data and syntaxes generated and analyzed during this research will be treated with complete confidentiality due to the requirements of the Human Research Ethics Committee. However, the data and syntaxes that support the conclusions of this paper are available upon reasonable request to the main author of the study.

\section{Competing interests}

The authors declare that there are no conflicts of interest.

\section{References}

Abela, R. K. (2013). Evidências de validade para o inventário dimensional clínico da personalidade (IDCP) com base nos perfis de participantes com diagnóstico psiquiátrico. (Tese de Doutorado). Universidade Federal de São Paulo: São Paulo.

Al-Dajani, N., Gralnick, T. M., \& Bagby, R. M. (2016). A Psychometric Review of the Personality Inventory for DSM-5 (PID-5): Current Status and Future Directions. Journal of Personality Assessment, 98(1), 62-81. doi: 10.1080/00223891.2015.1107572

American Psychiatric Association. (2013). DSM-5: Manual diagnóstico e estatístico de transtornos mentais. Artmed Editora.

American Psychological Association, American Educational Research Association, \& National Council on Measurement in Education. (2014). Standards for psychological and educational testing. New York, NY: American Educational Research Association.

Butcher, J. N., Graham, J. R., Ben-Porath, Y. S., Tellegen, A., Dahlstrom, W. G., \& Kraemmer, B. (1989). The Minnesota Multiphasic Personality Inventory-2 (MMPI-2): Manual for administration and scoring. University of Minnesota Press. Minneapolis, MN.

Carvalho, L. D. F., \& Arruda, W. (2016). Review of the Isolation Dimension of the Dimensional Clinical Personality Inventory. Temas em Psicologia, 24(1), 63-76. doi: 10.9788/TP2016.1-04

Carvalho, L. D. F., \& Primi, R. (2015). Development and internal structure investigation of the Dimensional Clinical Personality Inventory. Psicologia: Reflexão e Crítica, 28(2), 322-330. doi: 10.1590/1678-7153.201528212

Carvalho, L. D. F., \& Primi, R. (2016). Prototype matching of personality disorders with the Dimensional Clinical Personality Inventory. Psicologia: Teoria e Pesquisa, 32(2), 1-9. doi: 10.1590/0102-3772e322214

Carvalho, L. D. F., \& Primi, R. (no prelo). Manual técnico do Inventário Dimensional Clínico da Personalidade-2 (IDCP-2) [Technical Manual of the Dimensional Clinical Inventory of Personality-2 (IDCP-2)]. São Paulo, SP: Pearson.

Carvalho, L. D. F., \& Sette, C. P. (2017). Revision of the Criticism Avoidance dimension of the Dimensional Clinical Personality Inventory. Estudos de Psicologia (Campinas), 34(2), 219-231. doi: 10.1590/1982-02752017000200004

Carvalho, L. D. F., \& Silva, G. C. (2016). Review of the self-sacrifice dimension of the dimensional clinical personality inventory. Psicologia: Reflexão e Crítica, 29(1), 6. doi: 10.1186/s41155-016-0022-z

Carvalho, L. D. F., Bartholomeu, D., \& Silva, M. C. R. (2010). Instrumentos para avaliação dos transtornos da personalidade no Brasil. Avaliação Psicológica, 9(2), 289-298. Recuperado de http://pepsic.bvsalud.org/scielo.php?script=sci_arttext\&pid=S1677-04712010000200013

Carvalho, L. D. F., Pianowski, G., Silveira, F. J., Bacciotti, J. T., \& Vieira, P. G. (2016). Eccentricity dimension of the Dimensional Clinical Personality Inventory: Review and psychometric properties. Estudos de Psicologia (Natal), 21(4), 359-368. doi: 10.5935/16784669.20160035

Carvalho, L. D. F., Sette, C. P., \& Ferrari, B. L. (2016). Revision of the grandiosity dimension of the Dimensional Clinical Personality Inventory and verification of its psychometric properties. Trends in Psychiatry and Psychotherapy, 38(3), 147-155. doi: 10.1590/2237-60892015-0040

Cohen, J. (1992). A power primer. Psychological Bulletin, 112(1), 155-159. doi: 10.1037/0033-2909.112.1.155.

Conway, C. C., Forbes, M. K., Forbush, K. T., Fried, E. I., Hallquist, M. N., Kotov, R., ... \& Sunderland, M. (2019). A hierarchical taxonomy of psychopathology can transform mental health research. Perspectives on psychological science, 14(3), 419-436. doi: 10.1177/1745691618810696 
Crawford, M. J., Koldobsky, N., Mulder, R., \& Tyrer, P. (2011). Classifying personality disorder according to severity. Journal of Personality Disorders, 25(3), 321-330. doi: 10.1521/pedi.2011.25.3.321

Dammann, G. (2017). Schizoid personality disorder Psychosomatic. Medicine and General Practice, 2(4), e020484-e020484. doi: 10.26766/ PMGP.V2I4.84

DeShong, H. L., Lengel, G. J., Sauer-Zavala, S. E., O’Meara, M., \& Mullins-Sweatt, S. N. (2015). Construct validity of the five factor borderline inventory. Assessment. 22(3), 319-331. doi: 10.1177/1073191114548029

Esterberg, M. L., Goulding, S. M., \& Walker, E. F. (2010). Cluster A personality disorders: schizotypal, schizoid and paranoid personality disorders in childhood and adolescence. Journal of Psychopathology and Behavioral Assessment, 32(4), 515-528. doi: 10.1007 / s10862-010-9183-8

Gore, W. L., Tomiatti, M., \& Widiger, T. A. (2011). The home for histrionism. Personality and Mental Health, 5(1), 57-72. doi: 10.1002/ pmh.151

Haslam, N., Holland, E., \& Kuppens, P. (2012). Categories versus dimensions in personality and psychopathology: A quantitative review of taxometric research. Psychological Medicine, 42(5), 903-920. doi:10.1017/S0033291711001966

Hattie, J. (1985). Methodology review: assessing unidimensionality of tests and ltenls. Applied Psychological Measurement, 9(2), 139-164. doi: $10.1177 / 014662168500900204$

Hooper, D., Coughlan, J., \& Mullen, M. R. (2008). Structural equation modelling: guidelines for determining model fit. The Electronic Journal of Business Research Methods, 6(1), 53-60. Recuperado de: encurtador.com.br/egjnU

Hummelen, B., Pedersen, G., Wilberg, T., \& Karterud, S. (2015). Poor validity of the DSM-IV schizoid personality disorder construct as a diagnostic category. Journal of Personality Disorders, 29(3), 334-346. doi: 10.1521/pedi_2014_28_159

Huprich, S. K., Nelson, S. M., Meehan, K. B., Siefert, C. J., Haggerty, G., Sexton, J., ... \& Baade, L. (2018). Introduction of the DSM-5 levels of Personality Functioning Questionnaire. Personality Disorders: Theory, Research, and Treatment, 9(6), 553-563. doi:10.1037/per0000264

Kotov, R., Krueger, R. F., \& Watson, D. (2018). A paradigm shift in psychiatric classification: The Hierarchical Taxonomy of Psychopathology (HiTOP). World Psychiatry, 17(1), 24-25. doi: 10.1002/wps.20478

Kotov, R., Krueger, R. F., Watson, D., Achenbach, T. M., Althoff, R. R., Bagby, R. M., ... \& Eaton, N. R. (2017). The Hierarchical Taxonomy of Psychopathology (HiTOP): A dimensional alternative to traditional nosologies. Journal of Abnormal Psychology, 126(4), 454-477. doi: 10.1037/abn0000258

Krueger, R. F., Derringer, J., Markon, K. E., Watson, D., \& Skodol, A. E. (2012). Initial construction of a maladaptive personality trait model and inventory for DSM-5. Psychological Medicine, 42(9), 1879-1890. doi: 10.1017/S0033291711002674

Krueger, R. F., Eaton, N. R., Clark, L. A., Watson, D., Markon, K. E., Derringer, J., ... \& Livesley, W. J. (2011). Deriving an empirical structure of personality pathology for DSM-5. Journal of Personality Disorders, 25(2), 170-191. doi: 10.1521/pedi.2011.25.2.170

Lynam, D. R., Loehr, A., Miller, J. D., \& Widiger, T. A. (2012). A five-factor measure of avoidant personality: The FFAvA. Journal of Personality Assessment, 94(5), 466-474. doi: 10.1080/00223891.2012.677886

Marsh, H. W., Morin, A. J. S., Parker, P. D., \& Kaur, G. (2014). Exploratory Structural Equation Modeling: An Integration of the Best Features of Exploratory and Confirmatory Factor Analysis. Annual Review of Clinical Psychology, 10, 85-110. doi: 10.1146/annurevclinpsy-032813-153700

Matos, E. G., Matos, G., Mello, T., Matos, G., \& Mello, G. (2005). Importance and constraints of the DSM-IV use in the clinical practice. Revista de Psiquiatria do Rio Grande do Sul, 27(3), 312-318. doi: 10.1590/S0101-81082005000300010

Millon T. (2011). Disorders of Personality: introducing a DSM/ICD spectrum from normal to abnormal. New Jersey: Wiley.

Millon, T., Millon, C. M., Meagher, S. E., Grossman, S. D., \& Ramnath, R. (2004). Personality disorders in modern life. John Wiley \& Sons.

Mulay, A. L., \& Cain, N. M. (2017). Schizoid Personality Disorder. In Encyclopedia of Personality and Individual Differences (pp. 1-9). Springer International Publishing.

Mullins-Sweatt, S. N., Edmundson, M., Sauer-Zavala, S., Lynam, D. R., Miller, J. D., \& Widiger, T. A. (2012). Five-factor measure of borderline personality traits. Journal of Personality Assessment, 94(5), 475-487. doi: 10.1080/00223891.2012.6725044

Nunnally, J. C. (1978). Psychometric Theory. New York: McGraw-Hill.

Oldham, J. M. (2017). DSM Models of Personality Disorders. Current Opinion in Psychology, 21, 86-88 doi: 10.1016/j.copsyc.2017.09.010

Pianowski, G., Carvalho, L. F., \& Miguel, F. K. (2019). Investigating the Spectra constellations of the Hierarchical Taxonomy of Psychopathology (HiTOP) model for personality disorders based on empirical data from a community sample. Brazilian Journal of Psuchiatry, 41(2), 148-152. doi: 10.1590/1516-4446-2018-0015

Sadock, B. J., Sadock, V. A., \& Ruiz, P. (2017). Compêndio de Psiquiatria - Ciência do Comportamento e Psiquiatria Clínica. Artmed Editora.

Samuel, D. B., \& Griffin, S. A. (2015). A critical evaluation of retaining personality categories and types. In S. K. Huprich (Ed.). Personality Disorders: Toward Theoretical and Empirical Integration in Diagnosis and Assessment (pp. 43-62). American Psychological Association.

Santana, G. L., Coelho, B. M., Wang, Y. P., Chiavegatto Filho, A. D. P., Viana, M. C., \& Andrade, L. H. (2018). The epidemiology of personality disorders in the Sao Paulo Megacity general population. PloS One, 13(4), e0195581. doi: 10.1371/journal.pone.0195581

Sawilowsky, S (2009). New effect size rules of thumb. Journal of Modern Applied Statistical Methods, 8(2), 597-599. Recuperado de http:// digitalcommons.wayne.edu/coe_tbf/4

Tavakol, M., \& Dennick, R. (2011). Making sense of Cronbach's alpha. International Journal of Medical Educational, 2, 53-55. doi: 10.5116/ ijme.4dfb.8dfd

Teesson, M., Slade, T., \& Mills, K. (2009). Comorbidity in Australia: Findings of the 2007 National Survey of Mental Health and Wellbeing.

Australian and New Zealand Journal of Psychiatry, 43(7), 606-614. doi: 10.1080/00048670902970908

Tomiatti, M., Gore, W. L., Lynam, D. R., Miller, J. D., \& Widiger, T. A. (2012). A five-factor measure of histrionic personality traits. In N. Gotsiridze Columbus (Ed.), Psychological assessment (pp. 113-138). Hauppage, NY: Nova Science.

Triebwasser, J., Chemerinski, E., Roussos, P., \& Siever, L. J. (2012). Schizoid personality disorder. Journal of Personality Disorders, 26(6), 919926. doi: 10.1521/pedi.2012.26.6.919

Widiger, T. A., \& Costa, P. T. (2012). Integrating normal and abnormal personality structure: the five-factor model. Journal of Personality, 80(6), 1471-1506. doi: 10.1111/j.1467-6494.2012.00776.x

Widiger, T. A., Lynam, D. R., Miller, J. D., \& Oltmanns, T. F. (2012). Measures to assess maladaptive variants of the five-factor model. Journal of Personality Assessment. 94(5), 450-455. doi: 10.1080/00223891.2012.677887 
World Medical Association (WMA). (2013). Declaration of Helsinki: Ethical Principles for Medical Research Involving Human Subjects. JAMA, 310(20), 2191-2194. doi: 10.1001/jama.2013.281053.

Young, C. B., Chen, T., Nusslock, R., Keller, J., Schatzberg, A. F., \& Menon, V. (2016). Anhedonia and general distress show dissociable ventromedial prefrontal cortex connectivity in major depressive disorder. Translational Psychiatry, 6(5), e810. Recuperado de https:// www.nature.com/articles/tp201680

\section{Sobre os autores}

Lucas de Francisco Carvalho é psicólogo (Universidade Presbiteriana Mackenzie), doutor em avaliação psicológica pela Universidade São Francisco (USF). Atualmente, é Professor no Programa de Pós-Graduação Stricto Sensu em Psicologia da USF.

André Pereira Gonçalves é psicólogo (Unifenas-Alfenas), especialista em avaliação psicológica pela PUC-Minas, mestre e doutorando em Psicologia com área de concentração em avaliação psicológica pela Universidade São Francisco (USF).

Ana Paula Salvador é psicóloga (Unifenas-Alfenas), especialista em avaliação psicológica pela PUC-Minas, mestra e doutoranda em Psicologia com área de concentração em avaliação psicológica pela Universidade São Francisco (USF).

\section{Como citar este artigo}

Carvalho et al. (2020). Development and Preliminary Psychometric Evaluation of the Dimensional Clinical Personality Inventory Schizoid Personality Disorder Scale. Avaliação Psicológica, 19(3), 289-297. http://dx.doi.org/10.15689/ap.2020.1903.16758.07 